\title{
Analysing the critical factors influencing trust in e-government adoption from citizens' perspective: A systematic review and a conceptual framework
}

\author{
Latifa Alzahrani*, Wafi Al-Karaghouli, Vishanth Weerakkody \\ College of Business, Arts and Social Sciences, Brunel Business School, Brunel University London, Uxbridge, UB8 3PH, United Kingdom
}

\section{A R T I C L E I N F O}

\section{Article history:}

Received 13 October 2015

Received in revised form 11 May 2016

Accepted 10 June 2016

Available online 18 July 2016

\section{Keywords:}

E-government

Adoption

Citizens'trust

Antecedents of trust

\begin{abstract}
A B S T R A C T
Although the success adoption of e-government contingent upon citizens' trust and their willingness to use it, little consideration has been paid to explore the adoption of e-government from citizens' trust perspective. This paper provides a critical and systematic review of the current literature on citizens' trust in e-government, with a particular focus on the most critical factors influencing citizens' trust in respect of the adoption of e-government. The extant literature was identified through six electronic databases, from 2000 to 2014 . Academic articles were reviewed if they contained a relevant discussion of the antecedents or factors influencing citizens' trust in e-government adoption. The findings of this review reveal that several studies have been conducted in the area of trust in e-government (particularly trust in government and trust in the internet) with limited consideration paid to citizen's aspects of trust (such as personality, culture, gender, experience, education level, beliefs and value of systems). Based on the findings of the critical review, a conceptual framework is proposed by developing further the updated DeLone and McLean IS Success Model, which presents the antecedents of trust in e-government adoption.
\end{abstract}

Crown Copyright @ 2016 Published by Elsevier Ltd. All rights reserved.

\section{Introduction}

The electronic government or e-government encompasses the utilization of information and communication technology (ICT) to provide effective delivery of government's services and information to citizens, businesses and other government agencies (Bélanger \& Carter, 2008; Carter \& Weerakkody, 2008; Layne \& Lee, 2001; Moon, 2002; Rose, Persson, Heeager, \& Irani, 2015). Many scholars (e.g. Weerakkody \& Dhillon, 2008; Bannister \& Connolly, 2011; Janssen \& Shu, 2008; Lips, Gil-Garcia, \& Sorrentino, 2012; Weerakkody, Janssen, \& Dwivedi, 2009) argue that the successful adoption and acceptance of e-government provides potential advantages for citizens, business and other government agencies. However, in many countries, some citizens still do not trust using online services and e-government applications, which impact the adoption of e-government (Al-Busaidy \& Weerakkody, 2009; Cullen \& Reilly, 2007; McLeod \& Pippin, 2009; Ndou, 2004;

\footnotetext{
* Corresponding author.

E-mail addresses: Latifa.Alzahrani@brunel.ac.uk (L. Alzahrani),

Wafi.Al-Karaghouli@brunel.ac.uk (W. Al-Karaghouli),

Vishanth.Weerakkody@brunel.ac.uk (V. Weerakkody).
}

Palanisamy, 2004; Seifert \& Petersen, 2002). In addition, Khasawneh and Abu-Shanab (2013) and Al-Hujran, Al-Debei, Chatfield, and Migdadi (2015) highlight that despite the advantages of e-government, there is still some rejection or even fear of e-government applications by the public. Therefore, trust is one of the most significant aspects in the implementation of e-government strategies, which will lead to recommendations from the users/citizens who experienced it to other citizens. According to Carter and Belanger (2005) and Colesca (2009), governments require to understand the factors influencing trust of citizens and other governments' agencies in e-government in order to achieve successful adoption of e-government services.

Trust in e-government services is a complex relationship because it includes many complicated issues that affect citizens' trust in government services (Alshehri, Drew, \& Alfarraj, 2012; Chopra \& Wallace, 2003; Bélanger \& Carter, 2008; Colesca, 2009; Mahmood, Osmani, \& Sivarajah, 2014). Trust in the context of online transactions has been discussed in e-commerce (Chang \& Cheung, 2005; McKnight, Choudhury, \& Kacmar, 2000); however, few studies have analysed the role that trust plays in e-government services (Gefen, Rose, Warkentin, \& Pavlou, 2005; Horst, Kuttschreuter, \& Gutteling, 2006; Joison, 2009; Schaupp, Carter, \& Hibbs, 2009). Carter and Weerakkody (2008) agreed that despite cultural 
differences in the adoption of e-government across countries, "trust" is a universal factor influencing the adoption of egovernment. Before using e-government services, it is important that citizens believe that their government will provide the effective managerial and technical resources that are required to implement and secure these online systems (Alshehri \& Drew, 2010; Colesca, 2009; Dwivedi, Weerakkody, \& Janssen, 2011). Moreover, citizens must be confident to use e-government and they must have the intention to engage in e-government services.

In the existing literature, several studies (Carter \& Belanger, 2005; Khasawneh \& Abu-Shanab, 2013; Navarrete, 2010; Teo, Srivastava, \& Jiang, 2008; Wang \& Lo, 2013; Wang \& Lu, 2010; Welch, Hinnant, \& Moon, 2005) have been conducted in the area of trust in e-government (particularly trust in government and trust in the internet) with limited consideration to citizen's aspects of trust (such as personality, culture, gender, experience, education level, beliefs and value systems etc). Al-Hujran et al. (2015) agreed that the existing literature focuses only on how the technical aspects of technology and government reputation influence citizens' trust at the adoption stage which is believed to be the major barrier to e-government adoption. Thus, studying the concepts of trust in e-government from citizens perspective is considered to have a major consideration as citizens' adoption is the major objective of e-government (Welch et al., 2005; Teo et al., 2008; Rehman, Kamal, \& Esichaikul, 2012; Khasawneh \& AbuShanab, 2013). Consequently, a lack of clear understanding of the factors and issues that influence trust in e-government from citizens' perspective is one of the main motivations of this research.

The aim of this paper is to investigate, examine and identify the critical factors influencing citizens' trust in e-government adoption from citizens' perspective. It also aims to develop a conceptual framework for trust in e-government based on DeLone and McLean IS Model which studies the influence of information quality, system quality and service quality in intention to use and users' satisfaction. The paper is structured as follows: Section 2 provides a background of the concept of trust. In Section 3, a methodology of the review is explained. Section 4 presents a reported analysis of the data conducted in Section 3. Section 5 presents the finding of the systematic review. In Section 6, based on the finding of the review, the D\&M IS Success model is developed as a framework to the antecedents of citizens' trust in e-government. Section 7 presents the theoretical and practical implications of this study. The final section concludes, with a presentation of the limitations and contributions of the research.

\section{Background}

\subsection{Definition of trust}

The concept of trust has appeared over the past 50 years with the development of human and social interaction (Paliszkiewicz, 2013). Trust is considered as an important part of a relationship because it shows how people interact and build relationships positively (Lewicki \& Wiethoff, 2000). Trust refers to a willingness to depend on an unfamiliar trustee where the trustor does not have "credible, meaningful information about, or affective bonds" for the trustee (McKnight, Choudhoury, \& Kacmar, 2002). Mayer, Davis, \& Schoorman, 1995, p.712) also define trust as "the willingness of a party to be vulnerable to the actions of another party based on the expectation that the other will perform a particular action important to the trustor, irrespective of the ability to monitor or control that other party". However, many researchers have difficulty defining this concept because of the multidimension nature of trust. For example, McAlister (1995, p. 25) reported that "although trust's importance has been acknowledged, the matter of how it develops and functions has received little systematic theoretical attention". In addition, Karvonen (1999) agreed that a lack of careful analysis of the concept of trust in sociological, philosophical and technical factors is one of the fundamental causes of the confusing picture of trust.

Researchers (e.g. Chopra \& Wallace, 2003; Colesca, 2009) have studied this concept in a many disciplines, including psychology, sociology, economics, computer science, organizational science and business and marketing. Each discipline focuses on different aspects of trust that cause complexity in defining trust.

- Psychological approach; According to psychology, trust is the psychological state of the individual in which the trustor risks being exposed to the trustee based on positive expectations and the intention of the trustee (Rotter, 1980; Rousseau, Sitkin, Burt, \& Camerer, 1998). In addition, Hamshar et al. (1968) Hamshar, Geller, \& Rotter (1968) agreed that trust is based on perceived control of the individual over their environment. Trust has three aspects: cognitive, emotional and behavioural. Cognitive trust is when the trustor makes a coherent decision to place his trust in the trustee. Emotional trust is when trust is built in the trustee in an emotional way; and behavioural trust is when trust is built on the basis of commitment (Schlenker et al., 1973).

- Sociology approach; According to sociologists, trust is the property pivotal to both individuals and social groups (Lewis \& Weigert, 1985). Consequently, culture, ethnicity and religious affiliation are important factors influencing trust (Rotter, 1971). According to Sherchan et al. (2013), trust in sociology is based on two viewpoints: individual and societal. The individual level is similar to its perception from psychology. On the other hand, the societal level focuses on a collective psychological state of the group.

- Economical approach; In this approach, trust focuses on the reputation of the trustee and the benefits or risks that will come from the trusting relationship. In order to earn a good profit and build the company reputation, it is important that everyone trusts each other (Ouchi, 1980; Dyer, 1997)

- Computer Science; There are two components of trust in computer science: user trust and system trust. The concept of user trust is extracted from psychology and sociology, according to which it is a subjective expectation an entity has about another's future behaviour (Mui, 2003). However, in e-commerce businesses, such as Amazon and eBay or on social media, trust is based on user feedback and past interactions between customers. This indicates that trust is based on rationality. Moreover, in such circumstances, trust in user feedback increases in response to positive experience and decreases otherwise. Trust in online systems was found to be of two types: direct and recommendation. Direct trust is developed by personal experience while recommendation trust is developed on the basis of someone else's experience. (Sherchan, Nepal, \& Paris, 2013)

The concept of system trust is based on its reliability, effectiveness and security (Sherchan et al., 2013), according to which the expectation is that a device or system will faithfully behave in a particular manner to fulfil its intended purpose (Yao et al., 2010). For instance, the trustworthiness of a computer device would depend upon the reliability and effectiveness of its hardware and software to perform the expected functions (Moreland et al., 2010). Moreover, according to Srivastava and Teo (2009), there are two risks associated with trust in technology: privacy and security risks.

- Organizational Science approach; Organizational science is a field of study which deals with the functionality of an 
organisation (Beatty, Reay, Dick, \& Miller, 2011). In an organizational science approach, trust operates at multiple levels. According to Rousseau et al. (1998), trust in an organisational context is based on a combination of institutional structures, group dynamics, and individual psychological processes. It was found by Beatty et al. (2011) that in organisations, trust exists at two levels: trust between two different organizations and the interpersonal trust that exists between two employees of two different organizations. Trust between organizations was found to be different from that of interpersonal trust between employees. However, both were found to play a significant part in bargaining and negotiation between two organizations.

The organisational science approach to trust also highlights that within an organisation, individuals, by virtue of the nature of their job function/designation and trusting relationships, are supposed to act in a trustworthy manner (Beatty et al., 2011). For example, office assistants have the authority to sign specific documents on behalf of their supervisors. In this example, trust was created not due to interpersonal relationships but in response to the office assistants' job function (Beatty et al., 2011).

- Business and marketing; Trust focuses on the relationship between users and service providers. Thus, in this approach, trust is studied in relation to the influencing factors such as, in the context of e-government, the factor of ease of use, the interface design and perceived usefulness increase trust between trustor and trustee (Gefen et al., 2005; Horst et al., 2006; Lee \& Rao, 2007, 2009).

Table 1 below, presents a sample of definitions of the term trust by some scholars $2008-2013$.

\subsection{Types of trust}

Investigating the concept of trust from different disciplines leads to many types or dimensions of trust. The different types of trust include the following:

A Knowledge-based trust: based on the knowledge available to the trustor about the capabilities of the trustee. According to Wang (2010), knowledge-based trust comes from familiarity and past experience with the other party, leading to the building of trust between two parties through reducing uncertainty.

B Institution-based trust: defined as "the belief that needed structure conditions are present (e.g. on the Internet) to enhance the probability of achieving a successful outcome" (McKnight et al., 2002). Some researchers (Abu-Shanab \& Al-Azzam, 2012;
Alsaghier, Ford, Nguyen, \& Hexel, 2009; Srivastava \& Teo, 2009) divided institution-based trust into structural assurance, defined as "guarantees, regulations, promises, legal resources, or other procedures ... in place to promote success" (p. 339), and situational normality, defined as "one's belief that the environment is in proper order and success is likely because the situation is normal" (p. 339).

C Calculative-based trust: based on people's calculations of the benefits and costs that the other party will face if engaged in an opportunistic behaviour. So citizens tend to trust when the other party has nothing to gain, or if the cost is higher than the benefit of an opportunistic behaviour (Dashti, Benbasat, \& Burton-Jones, 2010; Li, Hess, \& Valacich, 2008).

D Relation-based trust: based on the past relations between trustor and trustee. According to Rousseau et al. (1998), trust can also derive from repeated interactions between the trustor and trustee.

E Personality-based trust: based on belief in the other party, that is, the other party has specific attributes (Wang, 2010) such as competency -the skills, abilities, expertise to satisfy their needs; integrity - the belief that the online trader will behave in an honest way and will adhere to principles and standards; benevolence - whether the vendor focuses on making a profit or on customers' interest (Lean, Zailani, Ramayah, \& Fernando, 2009).

F Cognitive-based trust: refers to a situation where people build trust in the trustee based on their first impression rather than any previous interactions they have had (Wang, 2010). According to Li et al. (2008), people resort to using cognition or first impressions if they have not had a prior experience with the trustee. Some researchers (Abu-Shanab \& Al-Azzam, 2012; Karvonen, 1999; Srivastava \& Teo, 2009) also believe that, when dealing with an unfamiliar trustee, cognitive-based trust is implemented instead of knowledge-based trust.

G Disposition to trust: refers to a general propensity to trust others. Rotter (1971) states that a disposition to trust includes generalized expectations about the trustee, and whether the trustor has information or past experience or not.

\section{Methodology of the systematic review}

In order to study the role of trust in e-government, a deskresearch was carried out, leading to the systematic review of the published literature relevant to trust in e-government. This review is based on a literature review methodology proposed by Brereton, Kitchenham, Budgen, Turner, and Khalil (2007). According to Brereton et al. (2007), three significant phases were adopted to identify relating articles to IS research: review planning,

Table 1

Definitions of trust.

\begin{tabular}{|c|c|}
\hline Source & Definition of Trust \\
\hline Teo et al. (2008) & Trust is defined as a set of anticipations as shared by the people involved in an exchange. \\
\hline Alsaghier et al. (2009) & $\begin{array}{l}\text { Trust refers to the expectation or belief of a person that another entity will be able to perform a valued action for them in the absence } \\
\text { of their control over the entity's performance. }\end{array}$ \\
\hline Colesca (2009, p 32) & $\begin{array}{l}\text { "Trust involves the belief that others will, so far as they can look after our interest, that they will not take or harm us. Therefore, trust } \\
\text { involves personal vulnerability caused by uncertainty about the future behaviour of others, we cannot be sure, but we believe that they } \\
\text { will be benign, or at least not malign and act accordingly in a way which may possible put us to risk". }\end{array}$ \\
\hline Carter and Belanger (2005) & Trust is defined as perception of confidence in both the integrity and reliability of the electronic marketer. \\
\hline Chee-Wee et al. (2008: 1) & $\begin{array}{l}\text { "Trust is the subjective assessment of one party that another party will perform a particular transaction according to his or her } \\
\text { confident expectations in an environment characterized by uncertainty". }\end{array}$ \\
\hline Tolbert and Mossberger (2006) & $\begin{array}{l}\text { Trust is an evaluation as to whether or not institutions or political authorities discharge their responsibility as per the normative } \\
\text { expectations of the public }\end{array}$ \\
\hline $\begin{array}{l}\text { Moorman, Deshpande and } \\
\text { Zaltman (2013) }\end{array}$ & Trust means the willingness of a person to rely on an exchange partner in whom the person has confidence \\
\hline
\end{tabular}


Summary of Previous Studies on Trust in E-government

\begin{tabular}{|c|c|c|c|c|c|c|c|c|}
\hline \multirow[t]{2}{*}{ Author/Year } & \multirow[t]{2}{*}{ Aim of the Study } & \multicolumn{4}{|c|}{ Antecedents of citizens' trust (independent variable) } & \multirow{2}{*}{$\begin{array}{l}\text { Dependent } \\
\text { Variable }\end{array}$} & \multirow{2}{*}{$\begin{array}{l}\text { Research Approach } \\
\text { and Design }\end{array}$} & \multirow[t]{2}{*}{ Research Finding } \\
\hline & & Citizen's Aspects & Technology & $\begin{array}{l}\text { Government } \\
\text { Agencies }\end{array}$ & Risk & & & \\
\hline $\begin{array}{l}\text { Warkentin } \\
\text { et al. } \\
\text { (2002) }\end{array}$ & $\begin{array}{l}\text { This study presents how } \\
\text { government can encourage } \\
\text { citizen's adoption of e- } \\
\text { government by building trust }\end{array}$ & $\begin{array}{l}\text { Experience, } \\
\text { disposition to } \\
\text { trust, } \\
\text { characteristic- } \\
\text { based trust }\end{array}$ & $\begin{array}{l}\text { Institution structure } \\
\text { assurance }\end{array}$ & $x$ & $x$ & $\begin{array}{l}\text { Intention to use } \\
\text { e-government }\end{array}$ & $\begin{array}{l}\text { Quantitative. } \\
\text { A survey of over } 1,000 \\
\text { taxpaying citizens in } \\
\text { United States, Latin } \\
\text { America, Africa }\end{array}$ & $\begin{array}{l}\text { The study presents several ways in which governments can } \\
\text { increase citizen trust, which include cultural, risk, and } \\
\text { technology acceptance variables. }\end{array}$ \\
\hline $\begin{array}{l}\text { Carter and } \\
\text { Belanger } \\
(2005)\end{array}$ & $\begin{array}{l}\text { Study factors that influence } \\
\text { citizen adoption of e-government } \\
\text { initiatives. }\end{array}$ & $\times$ & $\begin{array}{l}\text { Trust in technology, } \\
\text { perceived usefulness, } \\
\text { ease of use, } \\
\text { compatibility, perceived } \\
\text { quality }\end{array}$ & $\begin{array}{l}\text { Trust in } \\
\text { government }\end{array}$ & $\times$ & $\begin{array}{l}\text { Intention to use } \\
\text { e-government }\end{array}$ & $\begin{array}{l}\text { Quantitative } \\
\text { approach. } \\
\text { A survey to } 105 \\
\text { citizens in US }\end{array}$ & $\begin{array}{l}\text { Perceived ease of use, compatibility and trustworthiness are } \\
\text { significant predictors of citizens' intention to use an } \\
\text { e-government service. }\end{array}$ \\
\hline $\begin{array}{l}\text { Welch et al. } \\
\text { (2005) }\end{array}$ & $\begin{array}{l}\text { Studying how Internet uses, } \\
\text { citizen satisfaction with e- } \\
\text { government and citizen trust in } \\
\text { government is interrelated. }\end{array}$ & $x$ & Internet use & $\begin{array}{l}\text { Overall } \\
\text { Satisfaction } \\
\text { with } \\
\text { government }\end{array}$ & $x$ & $\begin{array}{l}\text { Trust in e- } \\
\text { government }\end{array}$ & $\begin{array}{l}\text { Quantitative } \\
\text { approach. } \\
\text { A survey with a } \\
\text { sample of } 806 \text { US } \\
\text { citizens }\end{array}$ & $\begin{array}{l}\text { Government website use is positively associated with } \\
\text { e-government satisfaction and website satisfaction and that e- } \\
\text { government satisfaction is positively associated with trust in } \\
\text { government }\end{array}$ \\
\hline $\begin{array}{l}\text { Bélanger and } \\
\text { Carter } \\
(2008)\end{array}$ & $\begin{array}{l}\text { Analysing impact of trust and risk } \\
\text { perceptions on one's willingness } \\
\text { to use } \\
\text { e-government }\end{array}$ & $\begin{array}{l}\text { Disposition to } \\
\text { trust }\end{array}$ & Trust in technology & $\begin{array}{l}\text { Trust in } \\
\text { government }\end{array}$ & $\times$ & $\begin{array}{l}\text { Trust and risk } \\
\text { affect intention } \\
\text { to use } \\
\text { e-government }\end{array}$ & $\begin{array}{l}\text { Quantitative } \\
\text { approach. } \\
\text { Survey for } 214 \text { citizens } \\
\text { in USA }\end{array}$ & $\begin{array}{l}\text { Citizen confidence in government and technology is imperative } \\
\text { to the wide-spread adoption of e-government }\end{array}$ \\
\hline $\begin{array}{l}\text { Teo et al. } \\
\text { (2008) }\end{array}$ & $\begin{array}{l}\text { Examining the role of trust in e- } \\
\text { government's success using the } \\
\text { updated D\&M IS success model }\end{array}$ & $x$ & $\begin{array}{l}\text { Trust in technology, } \\
\text { information quality, } \\
\text { system quality, service } \\
\text { quality }\end{array}$ & $\begin{array}{l}\text { Trust in } \\
\text { government }\end{array}$ & $x$ & $\begin{array}{l}\text { Trust in } \\
\text { e-government } \\
\text { and user } \\
\text { satisfaction }\end{array}$ & $\begin{array}{l}\text { Mixed approach } \\
\text { Focus group and } \\
\text { online survey of } 214 \\
\text { Singapore e- } \\
\text { government website } \\
\text { users. }\end{array}$ & $\begin{array}{l}\text { The results show that trust in government, but not trust in } \\
\text { technology, is positively related to trust in e-government } \\
\text { websites. }\end{array}$ \\
\hline $\begin{array}{l}\text { Chee-Wee } \\
\text { et al. } \\
\text { (2008) }\end{array}$ & $\begin{array}{l}\text { This research studies the } \\
\text { relationship between citizens' } \\
\text { trust and website quality }\end{array}$ & $\times$ & $\begin{array}{l}\text { Quality of website, ease } \\
\text { of use, usefulness }\end{array}$ & $\times$ & $x$ & $\begin{array}{l}\text { Citizens' trust } \\
\text { in } \\
\text { e-government }\end{array}$ & $\begin{array}{l}\text { Quantitative } \\
\text { approach. } \\
\text { Survey of } 689 \text { US } \\
\text { citizens }\end{array}$ & $\begin{array}{l}\text { High quality } \\
\text { e-government websites, factors of ease of use and usefulness } \\
\text { have a positive effect on citizens' trust in e-government. }\end{array}$ \\
\hline $\begin{array}{l}\text { Alsaghier } \\
\text { et al. } \\
\text { (2009) }\end{array}$ & $\begin{array}{l}\text { Conceptualizing citizens' trust in } \\
\text { e-government: application of } \\
\text { Q methodology }\end{array}$ & $\begin{array}{l}\text { Disposition to } \\
\text { trust, familiarity }\end{array}$ & $\begin{array}{l}\text { Trust in technology, } \\
\text { perceived usefulness, } \\
\text { ease of use, website } \\
\text { quality }\end{array}$ & $x$ & $x$ & $\begin{array}{l}\text { Trust and risk } \\
\text { leading to } \\
\text { intention to use } \\
\text { e-government } \\
\text { services }\end{array}$ & $\begin{array}{l}\text { Mixed Approach } \\
\text { Survey for } 402 \\
\text { citizens, interviews } \\
\text { and focus group in } \\
\text { Saudi Arabia }\end{array}$ & $\begin{array}{l}\text { The factors that influence trust in } \\
\text { e-government are disposition to trust, familiarity, trust in } \\
\text { internet, website quality and perceived ease of use }\end{array}$ \\
\hline $\begin{array}{l}\text { Colesca } \\
(2009)\end{array}$ & $\begin{array}{l}\text { Identify the determinants of trust } \\
\text { in e-government }\end{array}$ & $\begin{array}{l}\text { Individual } \\
\text { demographic, } \\
\text { propensity to } \\
\text { trust, internet } \\
\text { experience }\end{array}$ & $\begin{array}{l}\text { Trust in technology, } \\
\text { perceived usefulness, } \\
\text { perceived quality }\end{array}$ & $\begin{array}{l}\text { Perceived } \\
\text { organizational } \\
\text { trust }\end{array}$ & $\begin{array}{l}\text { Risk } \\
\text { perception, } \\
\text { Privacy } \\
\text { concern }\end{array}$ & $\begin{array}{l}\text { Trust in } \\
\text { e-government }\end{array}$ & $\begin{array}{l}\text { Quantitative } \\
\text { approach. } \\
\text { Survey of } 793 \text { citizens } \\
\text { in Romania. }\end{array}$ & $\begin{array}{l}\text { Technical and organizational trustworthiness, the quality and } \\
\text { usefulness, internet experience and propensity to trust, directly } \\
\text { enhanced trust in e-government, while age and privacy concerns } \\
\text { have a negative influence on trust. }\end{array}$ \\
\hline $\begin{array}{l}\text { Srivastava } \\
\text { and Teo } \\
\text { (2009) }\end{array}$ & $\begin{array}{l}\text { Citizen trust development for e- } \\
\text { government adoption and usage. }\end{array}$ & $\times$ & Trust in technology & $\begin{array}{l}\text { Trust in } \\
\text { government }\end{array}$ & $x$ & $\begin{array}{l}\text { Trust in } \\
\text { e-government }\end{array}$ & $\begin{array}{l}\text { Qualitative approach } \\
\text { Focus group and } \\
\text { interviews }\end{array}$ & $\begin{array}{l}\text { High level of trust in government and in technology leads to } \\
\text { citizens' trust in e-government. }\end{array}$ \\
\hline $\begin{array}{l}\text { Abdelghaffar } \\
\text { et al. } \\
\text { (2010) }\end{array}$ & $\begin{array}{l}\text { The impact of citizens' trust on } \\
\text { using e-government services. }\end{array}$ & $\begin{array}{l}\text { Characteristics of } \\
\text { the individual }\end{array}$ & Trust in technology & $\begin{array}{l}\text { Trust in } \\
\text { government }\end{array}$ & $x$ & $\begin{array}{l}\text { Trust in } \\
\text { e-government }\end{array}$ & $\begin{array}{l}\text { Quantitative } \\
\text { approach. } \\
\text { A paper-based survey } \\
\text { to } 2023 \text { students in } \\
\text { Egypt. }\end{array}$ & $\begin{array}{l}\text { Internet security and credibility of e-government services are } \\
\text { significant factors that contribute to citizens' trust towards e- } \\
\text { government }\end{array}$ \\
\hline $\begin{array}{l}\text { Liu and Zhou } \\
\text { (2010) }\end{array}$ & $\begin{array}{l}\text { Establishing an e-government } \\
\text { trust model from the behavioural } \\
\text { perspectives of citizen. }\end{array}$ & $x$ & $\begin{array}{l}\text { Perceived usefulness, } \\
\text { perceived ease of use }\end{array}$ & $x$ & $\begin{array}{l}\text { Perceived } \\
\text { security, } \\
\text { perceived } \\
\text { risk }\end{array}$ & $\begin{array}{l}\text { Satisfaction } \\
\text { and trust }\end{array}$ & $\begin{array}{l}\text { Quantitative } \\
\text { approach. } \\
\text { Online Survey from } \\
304 \text { citizens in China }\end{array}$ & $\begin{array}{l}\text { It is important to consider the role of trust as well as various } \\
\text { website quality attributes in understanding e-government } \\
\text { success. }\end{array}$ \\
\hline $\begin{array}{l}\text { Morgeson, } \\
\text { VanAmburg, } \\
\text { and Mithas } \\
\text { (2011) }\end{array}$ & $\begin{array}{l}\text { This study explores the structure } \\
\text { of the e-government-citizen trust } \\
\text { relationship }\end{array}$ & $\begin{array}{l}\text { Age, internet use, } \\
\text { education, } \\
\text { income and } \\
\text { gender }\end{array}$ & $x$ & $x$ & $\times$ & $\begin{array}{l}\text { Satisfaction, } \\
\text { confidant and } \\
\text { trust }\end{array}$ & $\begin{array}{l}\text { Quantitative } \\
\text { approach. } \\
\text { Telephone survey for } \\
787 \text { users of US federal } \\
\text { government }\end{array}$ & $\begin{array}{l}\text { E-government does not yet lead to greater satisfaction with an } \\
\text { agency interaction nor does it correlate with greater generalized } \\
\text { trust in the federal government overall. }\end{array}$ \\
\hline
\end{tabular}




\begin{tabular}{|c|c|c|c|c|c|c|c|c|}
\hline \multirow[t]{2}{*}{ Author/Year } & \multirow[t]{2}{*}{ Aim of the Study } & \multicolumn{4}{|c|}{ Antecedents of citizens' trust (independent variable) } & \multirow{2}{*}{$\begin{array}{l}\text { Dependent } \\
\text { Variable }\end{array}$} & \multirow{2}{*}{$\begin{array}{l}\text { Research Approach } \\
\text { and Design }\end{array}$} & \multirow[t]{2}{*}{ Research Finding } \\
\hline & & Citizen's Aspects & Technology & $\begin{array}{l}\text { Government } \\
\text { Agencies }\end{array}$ & Risk & & & \\
\hline $\begin{array}{c}\text { Navarrete } \\
(2010)\end{array}$ & $\begin{array}{l}\text { Investigating differences in trust } \\
\text { and consumption of public } \\
\text { services by citizens across two } \\
\text { settings: México and the US }\end{array}$ & $x$ & Trust in technology & $\begin{array}{l}\text { Trust in } \\
\text { government }\end{array}$ & $x$ & $\begin{array}{l}\text { Trust in } \\
\text { e-government } \\
\text { transactional } \\
\text { services }\end{array}$ & $\begin{array}{l}\text { Mixed approach. focus } \\
\text { group, interview \& } \\
\text { questionnaire } \\
\text { A total of } 455 \text { surveys, } \\
\text { from Mexico and US }\end{array}$ & $\begin{array}{l}\text { The effect of trust on the utilization of } \\
\text { e-government services varies depending on the cultural settings. }\end{array}$ \\
\hline $\begin{array}{l}\text { Wang and Lu } \\
\text { (2010) }\end{array}$ & $\begin{array}{l}\text { Trust in technology and trust in } \\
\text { government as two main factors } \\
\text { that determine trust in e- } \\
\text { government }\end{array}$ & $\times$ & $\begin{array}{l}\text { Trust in technology, } \\
\text { perceived usefulness, } \\
\text { perceived ease of use }\end{array}$ & $\begin{array}{l}\text { Trust in } \\
\text { government }\end{array}$ & $x$ & $\begin{array}{l}\text { Trust in } \\
\text { e-government }\end{array}$ & $\begin{array}{l}\text { Narrative literature } \\
\text { review }\end{array}$ & $\begin{array}{l}\text { Trust in internet and trust in government are important factors } \\
\text { leading to the development of trust in e-government }\end{array}$ \\
\hline $\begin{array}{l}\text { Beldad et al. } \\
\text { (2012) }\end{array}$ & $\begin{array}{l}\text { Factors influence internet users' } \\
\text { trust in government } \\
\text { organizations }\end{array}$ & $\begin{array}{l}\text { Disposition to } \\
\text { rust, internet } \\
\text { experience }\end{array}$ & Website quality & $\begin{array}{l}\text { Government } \\
\text { reputation, } \\
\text { past } \\
\text { experiences }\end{array}$ & $\begin{array}{l}\text { Security, } \\
\text { privacy }\end{array}$ & $\begin{array}{l}\text { Trust in } \\
\text { e-government }\end{array}$ & $\begin{array}{l}\text { Mixed approach. } \\
\text { Online survey to } 1,156 \\
\text { citizens and focus } \\
\text { group }\end{array}$ & $\begin{array}{l}\text { The quality of online government transaction and organizational } \\
\text { reputation increase trust in government organizations }\end{array}$ \\
\hline $\begin{array}{l}\text { Bannister } \\
\text { and } \\
\text { Connolly } \\
(2011)\end{array}$ & $\begin{array}{l}\text { Studying trust and } \\
\text { transformation for government, } \\
\text { governance and administration }\end{array}$ & $\begin{array}{l}\text { Characteristics of } \\
\text { the individual }\end{array}$ & Trust in technology & $\begin{array}{l}\text { Trust in } \\
\text { government }\end{array}$ & $x$ & $\begin{array}{l}\text { Trust in } \\
\text { e-government }\end{array}$ & $\begin{array}{l}\text { Systematic literature } \\
\text { review }\end{array}$ & $\begin{array}{l}\text { Technology enabled change has the ability to increase citizen } \\
\text { trust, Also, a framework is developed to examine trust in ICT } \\
\text { enabled changes. }\end{array}$ \\
\hline $\begin{array}{l}\text { Horsburgh } \\
\text { et al. } \\
\text { (2011) }\end{array}$ & $\begin{array}{l}\text { Relationships between public } \\
\text { trust in government and e- } \\
\text { government }\end{array}$ & $x$ & $x$ & $\begin{array}{l}\text { Trust in } \\
\text { government }\end{array}$ & Security & $\begin{array}{l}\text { Trust in } \\
\text { e-government }\end{array}$ & $\begin{array}{l}\text { Quantitative } \\
\text { Telephone survey to } \\
438 \text { in Australia and } \\
498 \text { in New Zealand }\end{array}$ & $\begin{array}{l}\text { No relationship between trust in government institutions and in } \\
\text { various e-government functions. }\end{array}$ \\
\hline $\begin{array}{l}\text { Rehman et al. } \\
\text { (2012) }\end{array}$ & $\begin{array}{l}\text { Determinants of trust in e- } \\
\text { government adoption:A case } \\
\text { study of Pakistan }\end{array}$ & $x$ & Trust in technology & $\begin{array}{l}\text { Trust in } \\
\text { government }\end{array}$ & $\begin{array}{l}\text { Perceived } \\
\text { risk, } \\
\text { security }\end{array}$ & $\begin{array}{l}\text { Trust in } \\
\text { e-government }\end{array}$ & $\begin{array}{l}\text { Quantitative } \\
\text { approach. } \\
\text { Online survey from } \\
150 \text { citizens in } \\
\text { Pakistan }\end{array}$ & $\begin{array}{l}\text { Perceived risk, trust in the internet, trust in the government, } \\
\text { information security and transaction security influence the } \\
\text { citizens' intention to adopt e-government. }\end{array}$ \\
\hline $\begin{array}{l}\text { Abu-Shanab } \\
\text { and Al- } \\
\text { Azzam } \\
(2012)\end{array}$ & $\begin{array}{l}\text { The effect of trust and risk on the } \\
\text { intention to use } \\
\text { e-government websites }\end{array}$ & $x$ & Trust in technology & $\begin{array}{l}\text { Trust in } \\
\text { government }\end{array}$ & $\begin{array}{l}\text { Perceived } \\
\text { risk }\end{array}$ & $\begin{array}{l}\text { Trust in } \\
\text { e-government }\end{array}$ & $\begin{array}{l}\text { Quantitative } \\
\text { approach. } \\
\text { A paper-based survey } \\
\text { for } 105 \text { citizens in } \\
\text { Jordan }\end{array}$ & $\begin{array}{l}\text { The results supported trust in government and the internet and } \\
\text { did not support perceived risk. }\end{array}$ \\
\hline $\begin{array}{l}\text { Wang and Lo } \\
\text { (2013) }\end{array}$ & $\begin{array}{l}\text { Studying the determinants of } \\
\text { citizens' intent to use e- } \\
\text { government websites in Taiwan }\end{array}$ & $\times$ & $\begin{array}{l}\text { Trust in technology, } \\
\text { perceived, usefulness, } \\
\text { perceived, ease of use }\end{array}$ & $\begin{array}{l}\text { Trust in } \\
\text { government }\end{array}$ & $\times$ & $\begin{array}{l}\text { Citizens' } \\
\text { intention to use } \\
\text { government } \\
\text { websites }\end{array}$ & $\begin{array}{l}\text { Quantitative } \\
\text { approach. } \\
200 \text { surveys from } 104 \\
\text { Online Survey } \\
\text { Company }\end{array}$ & $\begin{array}{l}\text { Trust in the government, perceived usefulness, perceived ease of } \\
\text { use, and attitudes toward the use of government websites have } \\
\text { positive effects on intent to use e-government }\end{array}$ \\
\hline $\begin{array}{l}\text { Ayyash et al. } \\
\text { (2013) }\end{array}$ & $\begin{array}{l}\text { Investigation into the relationship } \\
\text { between information system and } \\
\text { trust in } \\
\text { e-government }\end{array}$ & $x$ & $\begin{array}{l}\text { Perceived usefulness, } \\
\text { Ease of use, Information } \\
\text { quality, System quality, } \\
\text { Service quality }\end{array}$ & $\times$ & $\begin{array}{l}\text { Security, } \\
\text { privacy }\end{array}$ & $\begin{array}{l}\text { Trust in } \\
\text { e-government } \\
\text { and then } \\
\text { intention to use }\end{array}$ & $\begin{array}{l}\text { Quantitative } \\
\text { approach. } \\
\text { Survey of } 364 \\
\text { employees in ten } \\
\text { ministries in Palestine }\end{array}$ & $\begin{array}{l}\text { Quality of information, system, and service with perceived } \\
\text { usefulness, perceived ease of use, and security privacy } \\
\text { contributed positively to trust in e-government }\end{array}$ \\
\hline $\begin{array}{l}\text { Khasawneh } \\
\text { and Abu- } \\
\text { Shanab } \\
(2013)\end{array}$ & $\begin{array}{l}\text { E-government acceptance } \\
\text { factors: trust and risk }\end{array}$ & $x$ & Trust in internet & $\begin{array}{l}\text { Trust in } \\
\text { government }\end{array}$ & $x$ & $\begin{array}{l}\text { Trust and risk } \\
\text { affect the } \\
\text { intention to use } \\
\text { e-government }\end{array}$ & $\begin{array}{l}\text { Quantitative } \\
\text { approach. } \\
\text { Survey to } 149 \text { students } \\
\text { in Jordan }\end{array}$ & $\begin{array}{l}\text { Trust and risk as important factors that could affect the usage of } \\
\text { e-government application }\end{array}$ \\
\hline $\begin{array}{l}\text { Abu-Shanab } \\
\text { (2014) }\end{array}$ & $\begin{array}{l}\text { Studying antecedents of trust in } \\
\text { e-government }\end{array}$ & $x$ & $\begin{array}{l}\text { Trust in technology, } \\
\text { information quality }\end{array}$ & $\begin{array}{l}\text { Trust in } \\
\text { government }\end{array}$ & $\begin{array}{l}\text { Privacy } \\
\text { and } \\
\text { security }\end{array}$ & $\begin{array}{l}\text { Trust in e- } \\
\text { government }\end{array}$ & $\begin{array}{l}\text { Quantitative } \\
\text { approach. } \\
\text { A survey of over } 759 \\
\text { Jordanians }\end{array}$ & $\begin{array}{l}\text { Trust in government, trust in technology, information quality, } \\
\text { internet familiarity and privacy and security influence trust in } \\
\text { e-government }\end{array}$ \\
\hline
\end{tabular}


conducting the review and review's documentation. Figure presents the major steps required to each phase.

\subsection{Planning the review}

The first step to plan an effective review is to specify the research question. In this study, the research question is:

What are the critical factors influencing citizens' trust to adopt e-government services? And why?

In order to develop the review's protocol, a search was conducted in April 2014 for literature published in English between 2000 and 2014. Keywords were chosen in respect of the critical factors influencing citizens' trust in e-government, which include: "trust", "e-government", "factors", "adoption", "citizens' perspective" and "antecedents of trust". Published studies were identified through six electronic databases: Scopus, Summon, Proquest, ACM, ScienceDirect and Google Scholar. This resulted in the initial identification of 237 articles.

\subsection{Conducting the review}

The process of selecting relevant studies involved systematic analysis for each article by reading abstracts to ensure they met specific criteria, as follows: published in English, published after 2000 , and containing a relevant discussion of factors influencing citizens' trust in e-government. Articles that focused on the implementation of e-government or had a limited discussion of factors influencing citizens' trust in e-government were excluded.

Of the articles studied, 20 were found to meet the requirements of this study. In addition, reference lists of these articles were scanned in order to identify any further relevant articles that were not found in the initial search. Thus, two more articles were found relating to this research. Also, one unpublished study was involved as grey literature which meets the requirement of this review. A final number of 23 articles were found to be relevant to the aim of this study (see Table 2). Each article was read carefully to identify the important factors discussed as the antecedents of trust in e-government. These antecedents of trust were then grouped as common factors. The groupings were reviewed by all participating authors to validate the chosen factors. Four factors emerged from these articles: citizens' aspects, technology, government agencies and risk factors. The articles associated with each theme are listed in Table 2.

\subsection{Data reporting}

In order to report the data collected from the 23 articles, a sixcolumn table was designed to investigate the antecedents of trust in e-government in each article (see Table 2). The columns detail author and year, aim of study, antecedents of trust, dependent variable, research design \& research approach, and findings of each study. The column concerning antecedents of trust classifies on four factors: citizens' aspects, technology, governmental agencies' factors and risk factors. Each article is grouped into the type of antecedents focused upon in their studies (note: the " $\times$ " mark represents the absence of the correspondent factor in the article analysed), see Table 2 .

\section{Data analysis}

\subsection{Antecedents of trust in e-government}

Most of the published academic articles addressed technical factors and government agencies factors as important antecedents of trust in e-government (see Table 3 ). In addition, some studies
Table 3

Findings of antecedents of trust in e-government.

\begin{tabular}{ll}
\hline Antecedents of trust & Number of Articles \\
\hline Psychology & 1 \\
Government + Risk & 1 \\
Technology & 1 \\
Technology + Government & 8 \\
Technology + Risk & 2 \\
Technology + Citizens & 2 \\
Technology + Government + Risk & 3 \\
Technology + Government + citizens & 3 \\
Technology + Government + Risk +Citizens & 2 \\
\hline
\end{tabular}

identified perceived risk as a factor influencing citizens' trust. Perceived risk was studied along with other factors such as technical, and/or government agencies aspects. Furthermore, citizens' aspects were also discussed by many researchers as significant factors leading to trust in e-government. However, only two papers out of the 23 studied found to address all of the four factors influencing citizens' trust. The research studies by Beldad et al. (2012) and Colesca (2009) addressed factors, such as technology, government agencies, perceived risk and citizens' aspects as major factors influencing trust. However, the two studies by Beldad et al. (2012) and Colesca (2009) did not support their studies by theoretical context. They investigated the factors influencing trust in e-government with general expectations according to these factors. In addition, both studies did not examine the influence of trust in e-government with respect to citizens' satisfaction, intention to continue using and then the successful adoption of e-government.

\subsection{Theoretical foundation}

Regarding the use of a theory or model to develop the research model of trust in e-government, the majority of existing studies (11 studies) are not based on a theory or a model. Table 4 shows those studies, which are based on a model or a theory in their research studies. Most studies that use models utilize a Technology Acceptance Model (TAM) to explore the roles of trust in egovernment, by testing the factors of usefulness and ease of use as technical factors. This study also found that only two studies use D \& M IS Success Model to explore those factors influencing trust in e-government. Table 4 also presents some studies which utilized more than one model (e.g. Ayyash, Ahmad, \& Singh, 2013; Carter \& Belanger, 2005; Morgeson et al., 2011; Wang \& Lo, 2013).

\subsection{Research approaches}

Table 5 illustrates the research approach of the relevant papers that were reviewed. From the table, it is clear that quantitative methods have been the dominant methods used in most of the research studies. However, the review of the literature has shown that Qualitative methods were used by only one study, while four studies used a mixed methods approach (both quantitative and qualitative).

Table 4

Findings of Theoretical Foundation.

\begin{tabular}{ll}
\hline Theory/Model & Number of Articles \\
\hline Technology Acceptance Model (TAM) & 8 \\
Diffusions of Innovation theory (DOI) & 3 \\
Theory of Planned Behaviour TPB & 1 \\
D\&M IS Success Model & 2 \\
\hline
\end{tabular}


Table 5

Results of Research Approaches.

\begin{tabular}{ll}
\hline Research Approach & Number \\
\hline Quantitative Approach & 18 \\
Qualitative Approach & 1 \\
Mixed (Quantitative + Qualitative) & 4 \\
\hline
\end{tabular}

\section{Finding}

The systematic review that was conducted has covered qualitative, quantitative and mixed methods approaches, with the major focus on quantitative approaches. It is worth mentioning that the studies included in this review were conducted in a number of developed and developing countries, e.g. the USA, Romania, China, Singapore, New Zealand, Egypt, Saudi Arabia, Pakistan, Jordon and Africa (see Table 2). The findings of this review demonstrate that most researchers focused in their studies on technical and government agencies factors (Carter \& Belanger, 2005; Khasawneh \& Abu-Shanab, 2013; Navarrete, 2010; Teo et al., 2008; Wang \& Lo, 2013; Wang \& Lu, 2010; Welch et al., 2005). From the above findings, we can conclude that, this indicates there is a missing gap of the research in the antecedents of trust, which leads to the successful adoption of e-government services. Therefore, the antecedents of trust in the context of e-government should be studied in more detailed and analysed with reference to the four dimensions, i.e. technology, government agencies, citizens' aspects and risk. Each of these four dimensions may affect e-government adoption, as shown in Fig. 1. Thus, more research should be done to aim at addressing the factors of risk and citizens' aspects as these have been somewhat ignored by the extant research on this topic. Dwivedi et al. (2011) and Gefen (2002) also agree that it is important to study the issue of trust in e-government from a multidimensional construct in order to have a clear understanding of the concept of trust in e-government, and to address the issue of trust as a whole successfully.

\subsection{Technical factors}

In order to investigate the level of the citizen's confidence to use technology to interact with government agencies, several technical factors were identified as an important parameter. These factors also relate to the citizen's belief that using technology for governmental services will provide effective services, accurate information and ensure safe transactions (Carter \& Belanger, 2005; Moon, 2002; Pavlou, 2003). Technology has been studied by most researchers (Abu-Shanab \& Al-Azzam, 2012; Alsaghier et al., 2009; Ayyash et al., 2013; Carter \& Belanger, 2005; Liu \& Zhou, 2010; Navarrete, 2010; Rehman et al., 2012; Teo et al., 2008; Wang \& Lo, 2013; Khasawneh \& Abu-Shanab, 2013; Wang \& Lu, 2010; Warkentin, Gefen, Pavlou, \& Rose, 2002; Welch et al., 2005) because it is considered to be one of the primary antecedents of trust in e-government adoption.

The literature reveals that the technical factors of an e-government service have a major impact on the citizens' beliefs when they interact with e-government services. Some studies use the Technology Acceptance Model (TAM) to identify the technical factors influencing citizens' trust (Carter \& Belanger, 2005; CheeWee, Benbasat, \& Cenfetelli, 2008; Alsaghier et al., 2009; Liu \& Zhou, 2010; Morgeson et al., 2011; Wang \& Lu, 2010; Wang \& Lo, 2013; Ayyash et al., 2013). In the TAM, factors of usefulness and ease of use are the major technical factors that impact individual beliefs. Few studies utilize the D\&M IS Success Model to analyse the technical factors (Teo et al., 2008; Ayyash et al., 2013). The D\&M IS Success Model identifies three technical factors as major contributors to the success of IS projects: information quality, service quality and system quality. The existing literature also shows that while some studies use a model or theory to identify

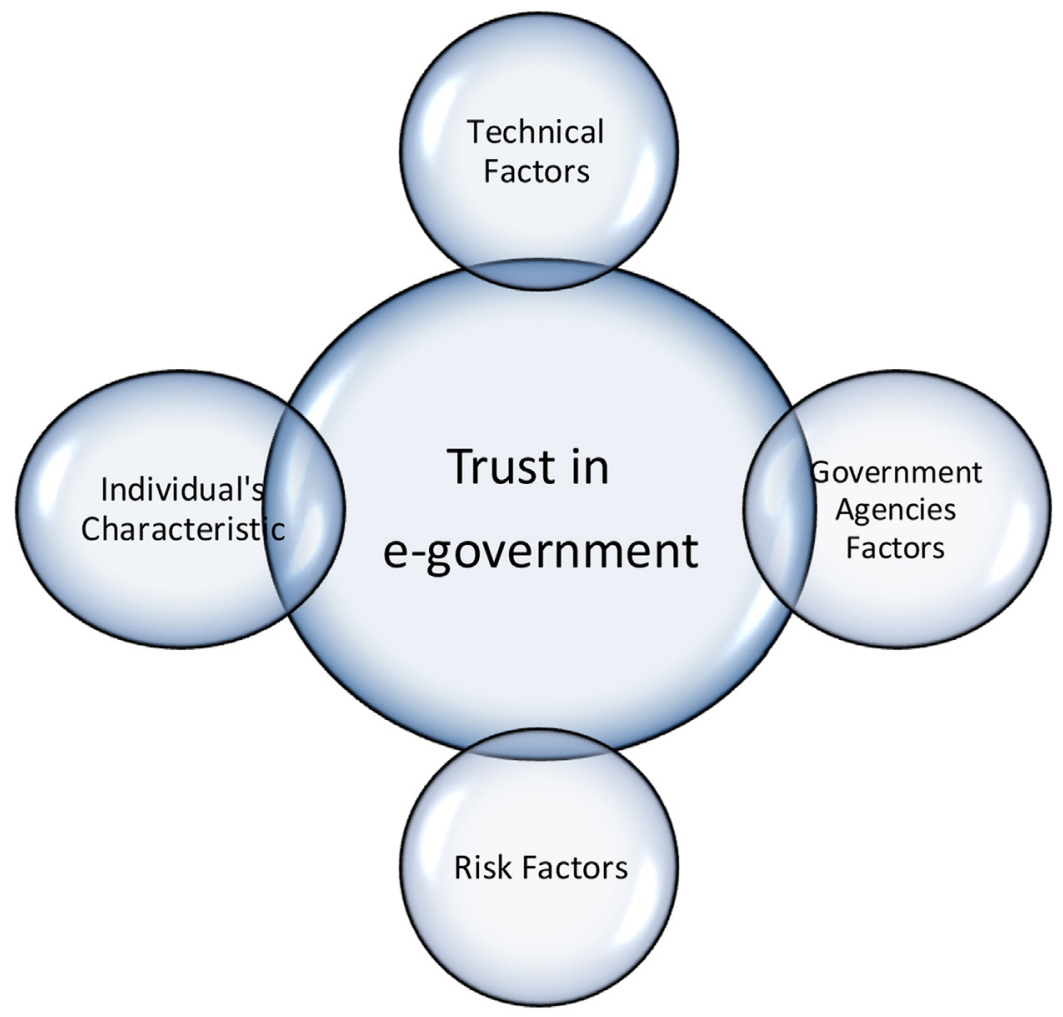

Fig. 1. Antecedents of Trust in e-government. 
the technical factors, most studies provides the overall aspect of trust in technology to predict citizens' trust in e-government.

\subsection{Factors relating to government agencies}

Government agencies were identified as factors to explore citizens' trust and their willingness to expose vulnerabilities regarding the government that depend on the level of citizens' confidence and belief in the ability of governments to provide affective services to their citizens. Papadakis (1999) demonstrates that citizens' confidence in their governments depends on their confidence in the performance of different government institutions. Many researchers (Ganesan \& Hess, 1997; Jarvenpaa, Tractinsky, \& Saarinen, 1999; McKnight et al., 2002) agree that trust in the government, which refers to the citizens' perceptions of the ability and integrity of governments to provide effective services to their citizens, is a significant dimension leading to the successful adoption of e-government services.

In e-government research, trust in the government is influenced by the reputation of governmental agencies (Srivastava \& Teo, 2009; Beldad, van der Geest, de Jong, \& Steehouder, 2012). Reputation refers to the citizens' belief that an agency is honest and concerned about its citizens (Jarvenpaa et al., 1999). Thus, agencies with a good reputation are perceived to be reluctant to jeopardize their reputational assets by acting opportunistically (Beldad et al., 2012; Srivastava \& Teo, 2009). In addition, past experience with a government agency's website is an important factor influencing trust in the government. Information that is provided by past experience affects citizens' confidence to use e-government services (Beldad et al., 2012).

\subsection{Perceived risk}

Perceived risk is defined as the "consumers' psychological perception of risks in the process of online shopping, the subjective forecast about the likelihood and the seriousness of loss" (Wang, 2010, p. 342). Many researchers (Liu \& Zhou, 2010; Horsburgh, Goldfinch, \& Gauld, 2011; Abu-Shanab \& Al-Azzam, 2012; Rehman et al., 2012; Ayyash et al., 2013) agree that there is a strong correlation between trust and risk. A large body of research (Rotchanakitumnuai, 2007; Ruizhong, Xiaoxue, \& Zixian, 2010; Wang, 2010) discusses the various dimensions of perceived risk, such as financial risk - the loss of money through online services; time risk - the loss of time in search or ordering a service; and finally, technology risk - which considers security and privacy as important issues (Rotchanakitumnuai, 2007; Ruizhong et al., 2010).

\subsection{Citizens' aspects}

From the existing literature, it can be seen that the citizens' aspects (trustor) and their beliefs regarding another party significantly influences trust. Some researchers (Warkentin et al., 2002; Colesca, 2009; Beldad et al., 2012) highlight the factors of disposition to trust and internet experience as important factors that affect citizens' trust in adopting the services of e-government. Individuals vary significantly in their levels of trust (Mayer et al., 1995). Disposition to trust refers to "a tendency to be willing to depend on others" (McKnight et al., 2000), where some people are more naturally inclined to trust anything and anybody, including online entities, despite having limited information about them, while others require a great deal of information on the trust target before placing their trust in them. Consequently, low levels of disposition to trust decrease the level of trust in e-government, while high levels of disposition to trust increase the level of trust in e-government. Many studies highlight disposition to trust as an important factor influencing trust in e-government (Warkentin et al., 2002; Belanger \& Carert, 2008; Alsaghier et al., 2009; Colesca, 2009). In addition, some studies report that internet experience can affect one's tendency to trust in Internet technology, which influences citizens' trust in e-government services (Alsaghier et al., 2009; Beldad et al., 2012; Colesca, 2009).

\section{The conceptual framework and hypotheses}

In this section, a framework has been developed based on the relevant literature, for the antecedents of citizens' trust in e-government. This framework is specifically based on DeLone and McLean's IS success model (2003), also referred to as the D\&M model.

The D\&M model is widely referred to in the IS literature, which provides a comprehensive model related to information systems success. DeLone and McLean (1992) demonstrate that there are six factors influencing IS success: system quality, information quality, use, user satisfaction, individual impact, and organizational impact. Following the above, DeLone and McLean (2003) updated the D\&M IS Success model by using "intention to use" with the factor "use" and adding the factor service quality too. Thus, system quality, information quality and service quality were important technological factors in the IS success model, see Fig. 2.

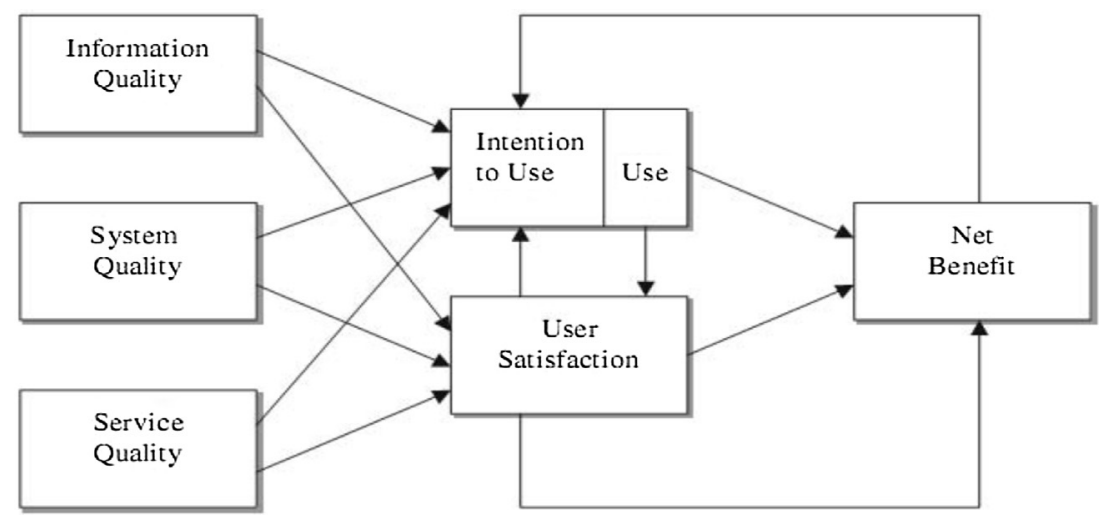

Fig. 2. DeLone and McLean's Updated Model. 
In 2009, Teo et al., utiliesed the D\&M IS Success Model to study the concept of trust in e-government. Their study confirms a significant relationship between trust and intention to use and user satisfaction. However, their study was limited to the technical factors and trust model without consideratuion to the multidimentional nature of trust. This paper will advance and develop their study by combining it with the study of Beldad et al. (2012). Beldad et al. (2012) identify three significant determinants influencing trust in online organization which are: internet user-based determinants of trust, organization-based determinants of trust and web-based determinants of trust.

In this paper, a proposed framework is developed by combining the both studies of Teo et al. (2008) and Beldad et al. (2012) with the major consideration of risk factors. Thus, in the proposed framework, four factors refer to the antecedents of trust in e-governmnet, i.e. technical factors, government agencies factors, risk, and citizens' aspects. These four antecedents impact trust in e-government, intention to continue use and citizens' satisfaction, while the organizational impact refers to the adoption of e-government services. Fig. 3 presents the proposed reseach framework based on the government-to-citizen (G2C) situation. The following subsections define each component of the research model.

\subsection{Antecedents of trust}

Antecedents of trust refer to the groups of factors that influence citizens' beliefs in using and adopting e-government services. From the systematic review, four factors were identified as influencing citizens to trust e-government: technical factors, government agencies factors, citizens' aspects and risk factors. Each of these factors is explained below.

- Technical factors: the D\&M model identifies three technological factors that influence citizens' beliefs: system quality, service quality and information quality. Information quality considers the accuracy, completeness and timeliness of the information on the e-government's website. System quality refers to the performance of the system and its reliability and accessibility. Service quality reflects the citizens' evaluation of the service quality with respect to the service that they actually receive and what they expect (Wang, 2010).

- Government agencies' factors: the reputation of an agency and past experience are fundamental factors of government agencies (Beldad et al., 2012). A good reputation will develop a citizen's trust to adopt e-government services. In addition, the past experiences of citizens and their satisfaction with respect to online services provided by government agencies are found to influence trust in e-government.

- Citizens'Aspects: Citizens' aspects are important factors influencing citizens' trust. In this research, gender, education, disposition to trust and internet experence are considered as citizens' aspects influencing trust in e-government.

- Risk factors: risk is a significant factor that impacts citizens' trust in e-government. Technological risk, such as security and privacy, and performance risk are considered as important types of risk impacting trust to adopt e-government.

\subsection{Citizens' belief}

- Trust in e-government: Trust in e-government refers to an individuals' beliefs and their expectation about e-government. Fig. 3 shows that trust in e-government is influenced by technical, government agencies, risk and citizens' aspects. Fig. 3 also shows that trust in e-government influences citizens' intention to use e-government.

- Intention to use: Intention to use an online website presents the citizen's willingness to engage in government services through that online website. Intention to use is influenced by acitizen's trust in e-government services. The D\&M model (2003) indicates that intention to use influences the individual's belief. In this model, intention to use e-government services influences citizens' satisfaction and their adoption of e-government services.

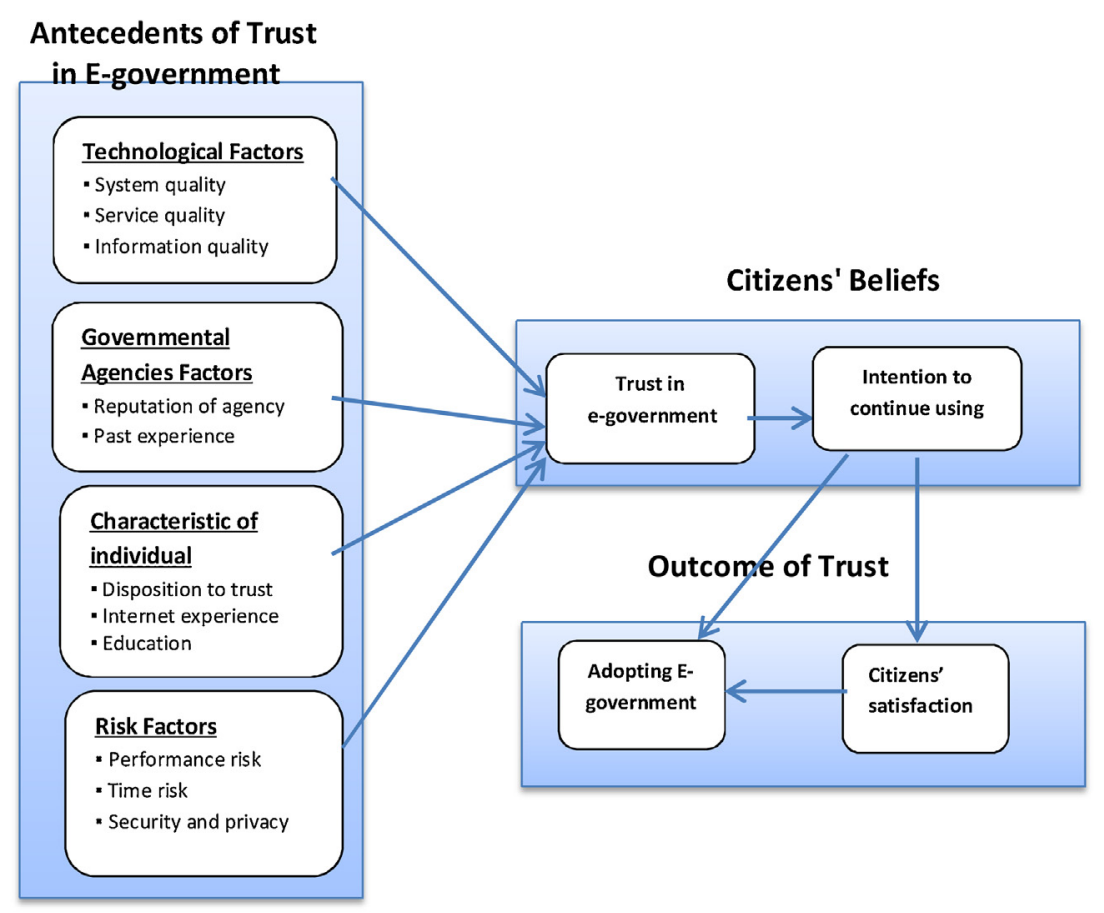

Fig. 3. Conceptual Framework for Antecedents of Trust in E-government. 


\subsection{Outcome of trust}

- Citizens'satisfaction: The extent to which an e-government service helps a citizen to achieve his/her needs. Citizens' satisfaction is influenced by their intention to use e-government. The D\&M model (2003) indictaes that a citizen's satisfaction influences his/her individual belief which is, in this framework, the adoption of e-government services (see Fig. 3).

- Adoption E-governmnet: the success outcome of citizens's trust in e-government is successful adopting of e-government services. Adopting e-government is influenced by citizens' satisfaction and their intention to use e-government services.

\section{Research implications}

This study provides four significant implications for research. Firstly, this study extends the literature of trust in e-government by providing comprehensive and a systematic literature in trust in e-government with major consideration to technical and nontechnical dimensions. The result reveals that trust in e-government is a multidimensional relationship as many factors influencing this relationship including technology, government agencies, citizens' aspects and risk factors. While the majority of researches in trust in e-government focus on trust in technology and trust in government agencies, citizens' aspects such as gender, education level, internet experience and disposition to trust are another significant dimensions influencing their trust in e-government.

Second, this study has developed a conceptual framework to address the critical factors influencing citizens' trust in e-government as the primary theoretical contribution of this study. The conceptual framework was developed based on the updated D\&M IS Success Model (2003) and Beldad et al. (2012). As most of studies in the field of trust in e-government use TAM model, this study utilize D\&M Model because it is more related to IS projects as it has three significant factors influencing IS success such as information quality, system quality and services quality. However, TAM model is limited to study the influence of two factors, i.e. usefulness and ease to use which are more related to any technology not IS projects. Thus, D\&M IS Success Model is more suitable for e-government research as IS projects.

Third, the updated D\&M IS Success Model is developed to consider not just technical factors, but also to investigate other factors such as government agency, risk and citizens' aspects. DeLone and McLean (1992) identified six factors for IS success which are: system quality, information quality, use, user satisfaction, individual impact, and organizational impacts. In 2003, DeLone and McLean updated D and M model by using "intention to use" in place of "use" and adding the factor service quality. However, the updated D\&M model still just focuses on technical factors for IS Success. This study developed this model to include other factors influencing trust in e-government as a multidimensional relationship.

Fourth, this study also provides some fundamental implications for practitioners, including government agencies. Government agencies need to consider some strategies to empower their citizens and increase their awareness about e-government systems. Abdelghaffar, Kamel, and Duquenoy (2010) mention that awareness increases the understanding of the activities that government agencies have. Thus, government agencies particular in developing countries are required to use the mass media for educative purposes and introducing the concepts of e-government. In addition, the government agencies could carry out seminars and training of their public service and encourage citizens to use the online applications and dissemination of web-based documents to ensure that this technological use is embraced. It could also carry out individual meetings and show support for the program through monitoring and evaluating sectors that have adopted e-government use (Srivastava \& Teo, 2009). In effect, publishing such information in newsletters, magazines, and holding presentations are some of the ways that government organizations attain knowledge of technological use. Further, Colesca (2009) agree that creating awareness is one way through which the government can enforce public enforcement of e-government. Essentially, individuals are willing and ready to take up change if they are aware of the benefits the systems they are adopting. Thus, awareness creates positive sentiments to enforce e-government.

Also, it is important to involve citizens in the development processes of e-government by soliciting their feedback. When users are involved in the development process and constantly asked how to improve the system and process, their level of satisfaction will be increased (Srivastava \& Teo, 2009). Having the users participate in the process, as well as consulting them for their views is an imperative approach to creating trust in e-government usage. According to Chun et al., 2010, citizens are not only recipients of e-government services, but they are also the key chain that guides policy formulation through their opinion and views. In addition, Carter and Bélanger (2005) demonstrate that $74.2 \%$ of government agencies in UK have a web site. However, $90.5 \%$ have not conducted a survey to see what online services citizens and businesses actually want. Thus, the citizens' level of trust in the institution increases when they are informed about the actions and the processes of the government.

\section{Conclusion}

\subsection{Summary of the research}

A systematic and critical review was conducted to provide an in-depth analysis of the factors influencing citizens' trust in the adoption of e-government services. The literature review of relevant academic articles has identified three significant issues. First, there is little evidence of research studies that identify the factors of trust in e-government from the multidimensional nature of trust. Most researchers (Khasawneh \& Abu-Shanab, 2013; Wang \& Lo, 2013; Abu-Shanab \& Al-Azzam, 2012; Rehman et al., 2012; Bannister \& Connolly, 2011) focus on two dimensions of trust in e-government, which are trust in technology and trust in government, with limit consideration of other factors such as the psychology of citizens and any risk factors. Second, the literature review revealed that the existing studies investigating the factors that influence citizens' trust are limited to the theory of the Technology Acceptance Model (TAM) or Diffusion of Innovation Theory (DOI), which again both focus on technology. In addition, most of the conceptual frameworks used in these studies were conceptualized with a general approach and limited focus on the specific nature of trust. Third, in the existing studies of trust in egovernment, there is a lack of research regarding the concept of trust, the multidimensional nature of trust, and the properties and types of trust. Thus, the majority of the extant research studies focus on the technology or government factors, without giving more consideration to the trust dimensions.

This paper suggests a conceptual framework for the antecedents of trust in e-government based on the literature gap and the D\&M IS Success Model, which yet to be tested. It is hoped that the proposed framework extends the D\&M IS Success Model to include not only technological factors. But, other factors that should be considered, such as government agencies factors, risk, and citizens' psychologies as antecedents of trust in e-government. 


\subsection{Research contributions}

Four primary contributions are the result of this research. First, this study reviews literature that informs on trust in e-government by exploring the concept of trust and the concept of e-government. By integrating the literature on the concepts of trust and e-government, this study provides a comprehensive understanding of trust in e-government. Second, this study highlights the antecedents of citizens' trust in e-government by a systematic review of the literature on trust in e-government. In this paper, four types of antecedents influencing citizens' trust to adopt e-government are investigated: technology, government agencies, risk, and citizen's aspects. Finally, a conceptual framework is proposed based on the D\&M IS Success Model, which explores the technical factors for IS Success and explains how these factors influence citizens' beliefs. This study developed this conceptual framework by integrating other factors (such as organizational factors, risk, and citizen's aspects) that influence trust in egovernment and the subsequent adoption of e-government services.

\subsection{Limitation and further research directions}

Like any other study, this study had limitations, especially, as it is an ongoing research. The first, is that, the results of this study are based on secondary data analysis of citizens' trust in e-government. Therefore, the results of this research cannot be considered as complete unless the proposed framework is justified with the support of primary data. The second limitation is that the review of the existing literature was identified from six electronic databases, with consideration of the keywords: "trust"; "e-government"; "adoption"; "citizens' perspective"; and "antecedents of trust". Future researchers might explore additional related journals and databases with the use of other combinations keywords such as "digital" and "culture".

\section{References}

Abdelghaffar, H., Kamel, S., \& Duquenoy, P. (2010). Studying eGovernment trust in developing nations: a case of university and colleges admissions and services in Egypt. Communications of the IIMA, 10(2), 93-107.

Abu-Shanab, E., \& Al-Azzam, A. (2012). Trust dimensions and the adoption of egovernment in Jordan. International Journal of Information Communication Technologies and Human Development, 4(1), 39-51.

Al-Busaidy, M., \& Weerakkody, V. (2009). E-government diffusion in Oman: a public sector employees' perspective, Transforming Government: people. Process and Policy, 3(4), 375-393.

Al-Hujran, O., Al-Debei, M., Chatfield, A., \& Migdadi, M. (2015). The imperative of influencing citizen attitude toward e-government adoption and use. Computers in Human Behavior, 53, 189-203.

Alsaghier, H., Ford, M., Nguyen, A., \& Hexel, R. (2009). Conceptualizing citizen's trust in e-government: application of Q methodology. Electronic Journal of egovernment, 7(4), 295-310.

Alshehri, M., \& Drew, S. (2010). Challenges of e-Government services adoption in Saudi Arabia from an e-ready citizen perspective. World Academy of Science, Engineering and Technology, 66(21), 1053-1060.

Alshehri, M., Drew, S., \& Alfarraj, O. (2012). A comprehensive analysis of Egovernment services adoption in Saudi Arabia: obstacles and challenges. IJACSA) International Journal of Advanced Computer Science and Applications, 3, 2 Available at: http://aisel.aisnet.org/cais/vol25/iss1/31.

Ayyash, M., Ahmad, K., \& Singh, D. (2013). Investigating the effect of information systems factors on trust in E-Government initiative adoption in palestinian public sector. Research Journal of Applied Sciences, Engineering and Technology, 5 (15), 3865-3875.

Bélanger, F., \& Carter, L. (2008). Trust and risk in e-government adoption. The Journal of Strategic Information Systems, 17(2), 165-176.

Bannister, F., \& Connolly, R. (2011). Trust and transformational government: a proposed framework for research. Government Information Quarterly, 28(2), $137-147$.

Beatty, P., Reay, I., Dick, S., \& Miller, J. (2011). Consumer trust in e-commerce web sites: a metastudy. ACM Computing Surveys, 43(3), 1-46.

Beldad, A., van der Geest, T., de Jong, M., \& Steehouder, M. (2012). A cue or two and I'll trust you: determinants of trust in government organizations in terms of their processing and usage of citizens' personal information disclosed online. Government Information Quarterly, 29(1), 41-49.

Brereton, P., Kitchenham, B., Budgen, D., Turner, M., \& Khalil, M. (2007). Lessons from applying the systematic literature review process within the software engineering domain'. Journal of Systems and Software, 80(4), 571-583.

Carter, L., \& Belanger, F. (2005). The utilization of e-government services: citizens trust, innovation and acceptance factors. Information Systems Journal, 15, 5-25.

Carter, L., \& Weerakkody, V. (2008). E-government adoption: a cultural comparison. Information Systems Frontier, 10(4), 473-482.

Chang, M. K., \& Cheung, W. (2005). Online trust production: interactions among trust building mechanisms. 38th hawaii international conference on system science.: IEEE.

Chee-Wee, T., Benbasat, I., \& Cenfetelli, R. T. (2008). Building citizen trust towards eGovernment services: do high quality websites matter? Proceedings of the 41st hawaii international conference on system sciences.

Chopra, K., \& Wallace, W. (2003). Trust in m-Electronic environments. Proceedings of the 36th IEEE hawaii international conference on system sciences1-10.

Colesca, S. E. (2009). Increasing E-Trust: a solution to minimize risk in EGovernment adoption. Journal of Applied Quantitative Methods, 4(1), 31-44.

Cullen, R., \& Reilly, P. (2007). Information privacy and trust in government: a citizen Based perspective from New Zealand. Proceedings 40th hawaii international conference on information systems.

Dashti, A., Benbasat, I., \& Burton-Jones, A. (2010). Trust, felt trust, and E-Government adoption: a theoretical perspective. Proceedings of the JAIS theory development workshop on sprouts: working papers on information systems, 10, 830 Retrieved from http://sprouts.aisnet.org/10-83.

DeLone, W. H., \& McLean, E. R. (1992). Information systems success: the quest for the dependent variable. Information Systems Research, 3(1), 60-95.

DeLone, W. H., \& McLean, E. R. (2003). The DeLone and McLean model of information systems success: a ten-year update. Journal of Management Information Systems, 19(4), 9-30.

DeLone, W. H., \& McLean, E. R. (2004). Measuring e-commerce success: applying the DeLone \& McLean information systems success model. International Journal of Electronic Commerce, 9(1), 31-47.

Dwivedi, Y., Weerakkody, V., \& Janssen, M. (2011). Moving towards maturity: challenges to successful E-government implementation and diffusion. ACM SIGMIS Database, 42, 4.

Dyer, J. H. (1997). Effective interfirm collaboration: how firms minimize transaction costs and maximize transaction value. Strategic Management Journal, 18(7), 535556.

Ganesan, S., \& Hess, R. (1997). Dimensions and levels of trust: implications for commitment to a relationship. Marketing Letters, 8(4), 439-448.

Gefen, D. (2002). Reflections on the dimensions of trust and trustworthiness among online consumers. ACM SIGMIS Database, 33(3), 38-53.

Gefen, D., Rose, G., Warkentin, M., \& Pavlou, P. (2005). Cultural diversity and trust in IT adoption: a comparison of potential e-voters in the USA and South Africat. Journal of Global Information Management, 13(1), 54-78.

Hamshar, J. H., Geller, J. D., \& Rotter, J. B. (1968). Interpersonal trust, internalexternal control, and the Warren Commission Report. Journal of Personality and Social Psychology, 9(3), 210-215.

Horsburgh, S., Goldfinch, S., \& Gauld, R. (2011). Is public trust in government associated with trust in E-Government? Social Science Computer Review, 29(2), 232-241.

Horst, M., Kuttschreuter, M., \& Gutteling, J. (2006). Perceived usefulness, personal experiences, risk perception and trust as determinants of adoption of egovernment services in the Netherlands. Computers in Human Behavior, 23(4), 1838-1852.

Janssen, M., \& Shu, W. S. (2008). Transformational government: basics and key issues. Proceedings of the 2nd International Conference on Theory and practice of electronic governance, vol. 1, 117-122.

Jarvenpaa, S. L., Tractinsky, N., \& Saarinen, L. (1999). Consumer trust in an Internet store: a cross-cultural validation. Journal of Computer-Mediated Communication 5(2) [Retrieved from http://jcmc.indiana.edu/vol5/issue2/jarvenpaa.html].

Joison, A. N. (2009). Privacy concerns, trust in government and attitudes to identity cards in the United Kingdom. 42nd hawaii international conference on systems sciences. big island, hawaii IEEE.

Karvonen, K. (1999). Creating trust. Proceedings of the fourth nordic workshop on secure IT systems (pp. 21-36)..

Khasawneh, R. W., \& Abu-Shanab, E. (2013). E-government acceptance factors: trust and risk. The 6th international conference on information technology.

Layne, K., \& Lee, J. (2001). Developing fully functional e-government: a four stage model. Government Information Quarterly, 18(2), 122-136.

Lean, O. K., Zailani, S., Ramayah, T., \& Fernando, Y. (2009). Factors influencing intention to use egovernment services among citizens in Malaysia. International Journal of Information Management, 29, 458-475.

Lee, J., \& Rao, H. (2007). Perceived risks, counter-beliefs, and intentions to use anticounter-terrorism websites: an exploratory study of government-citizens' online interactions in a turbulent environment. Decision Support Systems, 43(4), $1431-1449$.

Lee, J., \& Rao, H. (2009). Task complexity and different decision criteria for online service acceptance: a comparison of two e-government compliance service domains. Decision Support Systems, 47(4), 424-435.

Lewicki, R. J., \& Wiethoff, C. (2000). Trust, trust development, and trust repair. In M. Deutsch, \& P. T. Coleman (Eds.), The Handbook of Conflict Resolution: Theory and Practice (pp. 86-107).San Francisco, CA: Jossey-Bass. 
Lewis, J. D., \& Weigert, A. (1985). Trust as a social reality. Social Forces, 63(4), 967985.

Li, X., Hess, T. J., \& Valacich, J. S. (2008). Why do we trust new technology? A study of initial trust formation with organizational information systems. The Journal of Strategic Information Systems, 17, 39-71.

Lips, A. M., Gil-Garcia, J. R., \& Sorrentino, M. (2012). Introduction to the transformational government minitrack. 2013 46th hawaii international conference on system sciences, vol. 1, 2592.

Liu, Y., \& Zhou, C. (2010). A citizen trust model for e-government. In software engineering and service sciences (ICSESS). EEE international conference on ( $p p$. 751-754). IEEE..

Mahmood, M., Osmani, M., \& Sivarajah, U. (2014). The role of trust in E-Government adoption: a systematic literature review. Twentieth americas conference on information systems.

Mayer, R. C., Davis, J. H., \& Schoorman, F. D. (1995). An integrative model of organizational trust. The Academy of Management Review, 20(3), 709-734.

McAlister, D. J. (1995). Affect- and cognition-based trust as foundations for interpersonal cooperation. The Academy of Management Journal, 38(1), 24-59.

McKnight, D. H., Choudhury, V., \& Kacmar, C. (2000). Trust in E-commerce vendors: a two-Stage model. Proceedings of the 21st international conference on information systems.

McKnight, D. H., Choudhoury, H., \& Kacmar, C. (2002). The impact of initial consumer trust on intentions to transact with a web site: a trust building model. The Journal of Strategic Information Systems, 11, 297-323.

McLeod, A. J., \& Pippin, S. E. (2009). Security and privacy trust in E-Government: understanding system and relationship trust antecedents. Proceedings of the 42nd hawaii international conference on system sciences 1-10.

Moon, M. J. (2002). The evolution of e-government amonge municipalities: rhetoric or reality? Public Administration Review, 62(4), 424-433.

Moorman, C., Deshpande, R., \& Zaltman, G. (2013). Factors affecting trust in market research relationship. Journal of Marketing, 57, 81-101.

Morgeson, F. V., VanAmburg, D., \& Mithas, S. (2011). Misplaced trust? Exploring the structure of the e-government-citizen trust relationship. Journal of Public Administration Research and Theory, 21(2), 257-283.

Mui, L. (2003). Computational models of trust and reputation: Agents, evolutionary games, and social networks. Ph.D. Thesis. http://groups.csail.mit.edu/medg/ people/lmui/docs/phddissertation.pdf.

Navarrete, C. (2010). Trust in e-government transactional services: a study of citizens' perceptions in Mexico and the US. System sciences (HICSS), 2010 43rd hawaii international conference on (pp. 1-10). IEEE.

Ndou, V. D. (2004). E-government for developing countries: opportunities and challenges. The Electronic Journal of Information Systems in Developing Countries, 18(1), 1-17.

Ouchi, W. G. (1980). Markets, bureaucracies: and cians. Administrative Science Quarterly, 25, 124-141.

Palanisamy, R. (2004). Issues and challenges in e-governance planning. Journal of Electronic Government, 1(3), 253-273.

Paliszkiewicz, J. (2013). The importance of building and rebuilding trust in organizations. Diversity, Technology, and Innovation for Operational Competitiveness: Proceedings of the 2013 International Conference on Technology Innovation and Industrial Management pp. S1_269-278.

Papadakis, E. (1999). Constituents of confidence and mistrust in Australian institutions. Australian Journal of Political Science, 34(1), 75-93.
Pavlou, P. (2003). Consumer acceptance of electronic commerce: integrating trust and risk with the technology acceptance model. International Journal of Electronic Commerce, 7(3), 69-103.

Rehman, M., Kamal, M., \& Esichaikul, V. (2012). Determinants of trust in egovernment adoption: a case study of Pakistan. Proceedings of the eighteenth americas conference on information systems.

Rose, J., Persson, J., Heeager, L., \& Irani, Z. (2015). Managing e-Government: value positions and relationships. Information Systems Journal, 25, 531-571.

Rotchanakitumnuai, S. (2007). The important risk factors of E-Government service adoption. Proceedings of the IEEE international conference on wireless communications networking and mobile computing3657-3660.

Rotter, J. B. (1971). Generalized expectancies for interpersonal trust. American Psychologist, 26(5), 443-452.

Rotter, J. B. (1980). Interpersonal trust, trustworthiness, and gullibility. American Psychologist, 35(1), 1-7.

Rousseau, D. M., Sitkin, S. B., Burt, R. S., \& Camerer, C. (1998). Not so different after all: a cross-discipline view of trust. The Academy of Management Review, 23(3), 393-404.

Ruizhong, D., Xiaoxue, M., \& Zixian, W. (2010). Dynamic trust model based on perceived risk. Proceedings of the IEEE international, conference on E-Business and E-Government (pp. 2037-2040)..

Schaupp, L. C., Carter, L., \& Hibbs, J. (2009). E-file adoption: a study of uUS. taxpayers' intentions. 42nd hawaii international conference on system sciences.

Seifert, J., \& Petersen, E. (2002). The promise of all things E: Expectations and challenges of emergent electronic government. Perspectives on Global Development and Technology, 1(2), 193-213.

Sherchan, W., Nepal, S., \& Paris, C. (2013). A Survey of trust in social networks. ACM Computer Survey, 44(4), 27-33.

Srivastava, S. C., \& Teo, T. S. (2009). Citizen trust development for e-government adoption and usage: insights from young adults in Singapore. Communications of the Association for Information Systems, 25(3), 359-378.

Teo, T., Srivastava, S., \& Jiang, L. (2008). Trust and electronic government success: an empirical study. Journal of Management Information Systems, 9(3), 99-131.

Tolbert, C. J., \& Mossberger, K. (2006). The effects of e-government on trust and confidence in government. Public Administration Review, 66(3), 354-369.

Wang, H. J., \& Lo, J. (2013). Determinants of citizens' intent to use government websites in Taiwan. Information Development, 29(2), 123-137.

Wang, T., \& Lu, Y. (2010). Determinants of trust in e-government. Proceedings of the international conference on computational intelligence.

Wang, H. (2010). Review of studies on online consumer trust. In proceedings of the IEEE second international conference on computational intelligence and natural computing (pp. 97-100)..

Warkentin, M., Gefen, D., Pavlou, P., \& Rose, G. (2002). Encouraging citizen adoption of e-government by building trust. Electronic Markets, 12(3), 157-162.

Weerakkody, V., \& Dhillon, G. (2008). Moving from e-government to t-government: a study of process reengineering challenges in a UK local authority context. International Journal of Electronic Government Research (IJEGR), 4(4), 1-16.

Weerakkody, V., Janssen, M., \& Dwivedi, Y. K. (2009). Handbook of research on ICTenabled transformational government: a global perspective. Hershey PA: Information Science Reference.

Welch, E. W., Hinnant, C. C., \& Moon, M. J. (2005). Linking citizen satisfaction with egovernment and trust in government. Journal of Public Administration Research and Theory, 1(53), 371-391. 